\title{
External Social Accounting Developments: Analysis and Discussion of Academic Critiques
}

\author{
Hamad Alhumoudi \\ $\mathrm{PhD}$ Candidate, University of Essex, UK \\ E-mail: hamad.1992@ hotmail.com
}

Received: October 10, 2016

Accepted: January 11, 2017

doi:10.5296/ber.v7i1.10134

URL: http://dx.doi.org/10.5296/ber.v7i1.10134

\begin{abstract}
This paper aims to analyse and discuss the development of external social accounting (ESA). In this paper, the ESA is defined as the firm's representation of its operations and their effects on society. The initial development of this concept began in the 1920s and it went through remarkable developments and achievements to arrive at its current stage at this time. This paper have reviewed the literature in development of this concept and it found that there are great developments in the area of ESA reporting, but that also a number of critical issues have been identified including reporting-performance gaps regarding deficiencies from the disclosure practice and social auditing practice. There are also evidences that a number of firms portray their contribution in ways that makes them appear generous, whereas, in the majority of cases, this can be established as untrue. This paper contributes to the existing literature by gathering many concepts (i.e. CSR, social accounting reporting) under the name of external social accounting, which mainly focus in the reporting of social activities. Also it contributes to the literature by providing an overview of the development and its critiques.
\end{abstract}

Keywords: Social Accounting, Auditing, External Social Accounting, CSR, Reporting, Environmental Reporting, Social Accounting Matrices, Sustainability.

\section{Introduction}

A large number of authors, scholars and researchers from around the world have studied the area of social and environmental accounting, which is considered to be major growth area within accounting over recent years (Mathew, 1997). This paper aims to analyse the developments in external social accounting (ESA) and discuss academic criticisms of these developments. It heavily follows the design and method used by Gray $(1999 ; 2006)$ and Foote et al (2010) that draw on secondary contextual data as well as being argumentative in nature to contest a number of implied assumptions in both conventional and critical accounting. This paper will be divided into three sections: Firstly, it will identify the concept 
of ESA. Secondly, it will analyse the development of ESA, followed by an examination of general academic criticisms concerning these developments. Finally, it will discuss the criticisms of ESA in the area of reporting. Based on the available evidence, it could be concluded that there are great developments in the area of ESA reporting, but that also a number of critical issues have been identified. These include reporting-performance gaps regarding deficiencies from the disclosure practice and social auditing practice. There are also evidences that a number of firms portray their contribution in ways that makes them appear generous, whereas, in the majority of cases, this can be established as untrue. This paper contributes to the existing literature by gathering many concepts (i.e. CSR, social accounting reporting) under the name of external social accounting, which mainly focus in reporting. Also it contributes to the literature by providing an overview of the development and its critiques.

\section{The Concept of External Social Accounting}

ESA is a sub-category of social accounting. The literature contains a number of definitions of social accounting (Epstein et al., 1976; Ramanathan, 1976; Mathews, 1993; Gray et al., 1987). Ramanathan (1976) states that it is a means of communication with people inside and outside a business. Estes (1976) states that social accounting is an instrument of measurement for the reporting of internal and external information, one that considers the ways in which society is impacted through the firm and its operations. Grojer and Stark (1977) state that social accounting leads to numerical and in-depth narrative information regarding the effect of the firm's activities on individuals. Gray (2002) notes that social accounting is related to the concept or theory, which includes everything beyond the traditional accounting model. However, there are a number of terms given by scholars when it comes to the actual practice of social accounting such as environment reporting, social responsibility reporting, corporate social reporting, sustainability reporting, or corporate social responsibility. These direct the communication of accounting to stakeholders outside the firm (Blowfield and Murray, 2011).

ESA is therefore related in part to a firm's representation of its operations and their effects on society (Kaspersen, 2013; Dey, 2007). This representation includes corporate claims regarding their concerns, and measures taken for social and environmental matters. A firm's conventional objective is the maximisation of profit. However, this could be in opposition to the corporate social activities of the firm. Thus it is stated that firms habitually filter this representation in order to provide a positive impression or reputation for the company (Gray, 1997; Blowfield and Murray, 2011).

\section{Analyses of Developments in External Social Accounting}

Initial developments regarding the concept of social accounting as a means to measure the effect of firm's operations on the society began in the 1920s (Wood and Wood, 2004). The concept of conventional accounting continued being challenged in 1930s (Berle and Means, 1932, cited in Mook, 2013). Social responsibility is a concept that has certain similarities with social accounting, and was the first to be analysed. The term 'social responsibility' was specifically stated in literature of the 1930s and 1940s. One of the pioneers in this field was (Bowen, 1995 cited in Idowu and Filho, 2009). He claimed that a link exists between a 
business and social responsibility and that in the future a business would be driven through its social responsibility (Bowen, 1953, cited in Carroll, 1999). In the 1950s, a number of sociologists began studying accounting approaches (Pyatt and Roe, 1977). The social accounting model was incorporated into national accounts in the 1960s (Horrigan, 2010). Social and economic factors were both included in macroeconomic planning, which is referred to as Social Accounting Matrices (SAM), as established by Stone and Brown (1962). The SAM framework was not just a statistical measure; it was also a framework for macroeconomic analysis, since information could be arranged regarding the social and economic structure of a firm, forming a database for a model of its economy. Hence the SAM framework was seen as relatively successful (Sen, 1996). In the 1970s, the ESA appeared in the form of the firm's account or reporting (Elibirt and Parket, 1973;Murphy, 1978;Hambrick and Chen, 2008).

During this time, the public became more conscious of social and environmental issues related to the provision of a good quality of life. This compelled firms to be more social responsible (Kaspersen, 2013;Thomson and Bebbington, 2005). Milovanović (2009) noted that through application of social accounting, companies are able to improve their market share, enhance their image, strengthen brands, and enhance their capability to attract and maintain employees. Linowes (1972) put forward the concept of a socio-economic operating statement, the aim of which was to quantify in financial terms the dealings of the organisation with products, individuals, and the environment. This was a revised form of traditional historical financial accounting, which took into account private (but not public) costs (Mathew, 1997). There is a great deal of discrepancy between this initial effort to develop models and quantify them, with the majority of the literature available on handling externalities as gains or cost to the environment of the future (Linowes, 1972). Mathew (1997) criticises this model, due to the fact that there was no arrangement for identifying or calculating the number of discharges and their environmental consequent impacts.

Dilley and Weygandt (1973) developed a statement of funds flow regarding the social related activities of a power station. Even though there was improved applicability of this statement than of Linowes (1972), it still focuses on the past and existing time, but not on the future. It also only uses a financial measurement. Thus, in this statement future costs to the public are not measured alongside existing costs, and there is no assessment of benefits (Mathews, 1993). Even environmental aspects are not divided from other social effects.

The ABT group developed a further model during this time. It included social financial income and a balance sheet through which there was an attempt to measure a firm's effect on clients, staff, owners, and society and the general public (ABT and Associates, 1971, cited in Mook, 2013). This was criticised as too vague and complex to be feasible for traditional accounting (Bauer \& Fenn, 1973). This criticism did not deter the development of other experiments. Estes (1976) suggested a similar development, known as the social impact statement (SIS). The terms 'social costs' and 'social benefit', and subsequently 'social deficit' or 'social surplus' were used.

However, at this time, disclosure or reporting was irregular, rhetorical, and unmatched among 
companies, while also having lack of a regulatory framework (American Institute of Certified Public Accounting, 1977). In the context of developments in theory, the majority of the contributions made during this time period were in order to establish a normative theory of corporate social reporting (Ulmann, 1985). Burton,(1977) and Mathews, (1997) argued that Ramathan's (1976) contribution to literature has been that of the development of the concept (but little to the practical applicability) of ESA.

In addition to the increase in interest in external social reporting (ESR) in the 1970s, there was increased public focus on social audit (Mook, 2013). This is a means of ensuring that reporting is reliable and to place increased pressure on a firm regarding their effect on society (Blowfield and Murray, 2011). Nevertheless, this concept is still difficult to explain in comparison with financial auditing (Kaspersen, 2013).

In the 1980s environmental matters formed an important part of corporate social reporting (Bebbington, 2007;Mook, 2013). This was due to a rise in public awareness regarding matters of the environment and sustainability. An example is the Brundtland Report (1987). The dominance of industrial standards during this time encouraged public attention to focus on environmentalism, resulting in increased public pressure (Blowfield and Murray, 2011). Thus, the key aspect was sustainability and this led to the initiation of sustainability reporting, which includes sustainability matters within ESR (Kaspersen, 2013; Schaltegger and Wagner, 2011).

Moreover, a considerable amount of experimental researches at this period became increasingly analytical rather than more descriptive, as the aim of these studies was to form philosophical reinforcements of corporate social reporting, leading to normative models becoming out-dated (Mathews, 1997). Nevertheless, there was still an absence of a common theoretical framework (Horrigan, 2010; Gray et al., 1997).

At the beginning of the 90s, a firm's disclosure was dominated by environmental issues rather than social elements (Adams et al., 2004;Mathews, 1997). This was a result of the growing emphasis on business ethics and the rise of the 'green revolution' (Gray et al., 2001). During this time period, even the triple bottom light was initiated (Scerri and James, 2010). This is an extended form of the concept of sustainability made at the onset of the 1980s. However, with regard to reporting, it is difficult to explain this concept since it requires a complex evaluation of the firms' dealings with society, the environment, and natural resources (Idowu and Filho, 2009). Nevertheless, there has still been focus on the triple bottom line as a feasible concept of sustainability (Gray and Milne, 2002). This has resulted in the formation of the sustainability reporting guidelines by the Global Reporting Initiative (GRI) (Mook, 2013). Although an appropriate technique is given in the guidelines, it could prove to be rather complex, due to the fact that successful implementation of this technique requires the complete participation of stakeholders (Schaltegger et al., 2006).

During the mid-90s, emphasis was again placed on social elements within corporate social reporting. Since then, issues of ethics, social responsibility and the environment are included in corporate social reporting (Adams et al., 2004; Owen et al., 2007). Nonetheless, further developments covers social auditing, and specifically environmental auditing (Dey et al., 
2007). After this time era, corporate social reporting and auditing rapidly developed, leading to the global rise of shadow and silent accounts (Ruffing, 2007). This occurred due to the process of globalisation and the rise of a number of techniques, theories, and terms (Gray, 2005).

Although numerous academics placed emphasis on the significance of the ESA and outlined the fundamental reasons for a firm to undertake like these reporting, there have been various considerations of business interface, which has resulted in various perspectives regarding 'why' 'what' and 'to whom' relating to ESA (Mook, 2013). This is most likely to become an area of dispute (Horrigan, 2010). These conflicting perspectives are classified into three distinct categories: Firstly, stakeholder accountability, which concerns the stewardship responsibilities of a firm to community. Thus, the management performance has to be assessed in the context of profit and the achievement of social targets (Brown and Fraser 2006). Secondly, the stakeholder management approach, which claims that the involvement of a firm in ESA is a means to handle its broader stakeholders and establish a good standing, instead of as management interference or as a trade-off contra profit (Blowfield and Murray, 2011). Thirdly, the critical theory approach, which cautions that although the concept of stakeholder management approach or stakeholder accountability sounds feasible in theory, the present imbalance of power and resources in society renders it impossible to possess true accountability or an accurate representation of the firm, particularly when there has been no major modification in a capitalist society (Sen, 1997).

\section{Discussion of Criticism of Developments in External Social Accounting}

These developments are progressive, but a number of critical issues have been identified and criticised by social accounting researchers. These could damage both the credibility of ESA reporting and its future progress. These issues are known as reporting shortcomings, and reporting rhetoric. A number of researchers have used different terms for this gap in their reports, such as the 'credibility gap'; 'assurance expectation gap'; 'portrayal gap' and 'legitimacy gap' (Gray and Milne, 2002; Adams, 2004; O’Dwyer and Owen, 2005; Dey, 2007; Spence, 2007;Ruffing, 2007). The gap can even be identified in a number of high profile Non-Governmental Organisation (NGO) reports and industry-sponsored surveys (Ruffing, 2007). The reporting deficiencies have been referred to by some researchers as 'reporting-performance gaps' and categorise various kinds of gaps, such as poor reliability or no completeness (Adams, 2004; Dey, 2007).

Dey (2007) states that the gap of 'no completeness' should be calculated or considered as a difference between the level of disclosure given in corporate reports and that promised by the reporting entity in its disclosure, or stated in the ESA reporting guidelines. Critics have identified a number of current shortcomings. These include little concept of sustainability, 'cherry-picked' information, and limited reporting (Milne et al., 2003; Spence, 2007). Researchers and academics have observed that firms reveal selective information in their social and environment reports (Adams and Evans, 2004; Adams, 2004). The most frequent form of 'no completeness' is this selective and limited reporting. Milne and co-authors chose reports from the UNEP/SustainAbility's benchmark tool for their study of benchmarking in 
New Zealand's early sustainability reports. The findings revealed the ways in which firms use a limited technique with partial disclosure (Milne et al., 2003). This study has been extended worldwide through their additional comparisons with leading international reporters (Mook, 2013).

The difference between the incomplete credibility, stated by the auditing practices in social and environmental reports, and the credibility assured in the credibility statements, signifies 'weak reliability' (Adams and Evans, 2004). There has been criticism of the existing assurance practices of ESA reporting, which is referred to as 'patchy'. Through such practices, the quality of the ESA reporting cannot be ensured (Casey, 2007; Dey, 2007). Similar outcomes have been observed in empirical researchers in published assurance statements. It indicated that existing practices lead to uncertainty and contains a good deal of inconsistency (Owen, 2007). It has been established through findings of studies that completeness with regard to providing adequate information is hardly addressed by assurance statements (Milovanović, 2009). O'Dwyer and Owen (2005) also noted that the entire assurance procedure in their study was subject to considerable managerial control. Overall, there has been little contribution of the existing assurance practices to the promised development of improved levels of credibility to the ESA report (Owen, 2007).

There is considerable speculation regarding the causes of reporting rhetoric and their deficiencies. These causes and primary reasons can be studied from the perspective of ESA reporting voluntarism and organisational motivations (Gray and Milne, 2002). There are multiple organisational motives, these differing for each firm (O'Dwyer and Owen, 2005). Managers' insufficient information regarding sustainability, along with socio-environmental and commercial disputes, have been cited as the major issues among many motives for conducting ESA reporting (Spence, 2007). Whereas, through voluntary ESA reporting, ESA reporting entities are able to selectively and directorially report their social and environmental performance (Mook, 2013). Voluntarism is criticised by accounting researchers as 'transformative potential', 'democratic potential' and even 'Implicit Managerialism' (Dey, 2007). They believe that the issues of completeness and credibility in ESA reporting can be addressed through mandatory regulation (Adams, 2004). Yet the possibility of mandatory regulations for ESA reporting does not appear to be implemented either now or near future (Milovanović, 2009). Moreover, there are rises in stakeholders' demands for accurate ESA reporting disclosure. The silent and shadow reporting are an alternative approaches that accounting scholars believe it may have a considerable potential to resolve the problems in existing ESA reporting (Sen, 1996). Dey (2007) states that two key initiatives exist that have attempted to involve and form silent and shadow reporting techniques. These are accounting academics and 'campaigning pressure groups' (primarily comprising of NGOs). Although, both are involved in the silent and shadow reporting, and have certain common interests with regard to disclosing deficiencies and corporate hegemonic discourse, their involvements are various as they are based on their own approaches, aims, and information sources of silent and shadow reporting (Kamoche, 2012).

In the shadow reporting, the campaigns of NGOs indicate a feasible and sensible method, and numerous sources of information (Gray and Milne, 2002). They directly aim for corporate 
ESA reporting by revealing the discrepancies between corporate 'propaganda' and the information provided to the public (Mook, 2013). Since they are overly keen to reveal the gaps in corporate social and environmental disclosures, these shadow reports have been criticised as having biased selection of shadow information, short-term behaviours, and a lack of consistency in reporting (Dey, 2007; O'Sullivan and O'Dwyer, 2009). However, the efforts of accounting academics in silent and shadow reporting demonstrate their keenness to reveal the issues in the present ESA reports, and even deliver educational guidelines for corporate ESA reporting (Manetti, 2011). Moreover, besides their theoretical attempts for (re) construction of silent and shadow reporting, Dey (2003) and Kaspersen (2013) have recommended a tentative structure for silent and shadow reporting which could assist in increased development and improvement of this counter accounting approach.

There could be various causes for the issues and challenges that are linked to the quality of ESA reporting (Skouloudis et al., 2010). Deficiencies can be clarified to some extent to the absence of stakeholder involvement (Milovanović, 2009; Skouloudis et al., 2010;Cooper and Owen, 2007), along with the flexible and voluntary nature of ESA reporting (Archel et al., 2008). When an ESA report does not include the involvement of stakeholders, the possibility arises that it is functioning from an organisational, rather than a stakeholder-focused, outlook (Adams, 2004), thus impacting on a firm's execution of accountability (Gray and Milne, 2004; Kamoche, 2012). Considering the flexible and voluntary method of ESA reporting, this dearth of stakeholder involvement becomes specifically challenging (Fonseca et al., 2013). For example, in the traditional financial accounting, firms prepare annual financial report and provide certain details according to the requirements of the corporate governance code and regulations of the country's it operates in (Kaspersen, 2013; Belal, 2002). This feature ensures that a report is of value and is reliable. Firms face lesser restraints concerning the data and preparation of non-financial reports in comparison to the restraints imposed on financial reports (Ruffing, 2007). This indicates that firms may be permitted to form these reports according to their own outlines (Archel et al., 2008). Since there are a diverse variety of likely topics in ESA reporting, firms have a great deal of choice in selecting the topics to include in their ESA reports (Moneva et al., 2006). Equally significant is that they can also select which topics to omit from including in the disclosure of their report (Cooper and Owen, 2007; Manetti, 2011).

The fundamental purpose of the ESA reporting of firms has been doubted by a number of critics (Milovanović, 2009), who claim that they are moving away from the primary aim of sustainability (Tregidga and Milne, 2006). They also claim that firms use ESA reports to accomplish their own economic and political objectives, rather than environmental and ethical objectives (Adams, 2004; Tregidga and Milne, 2006; Spence, 2007; Hopwood, 2009). For example, Hopwood (2009) expresses doubts when it comes to reasons for firms to develop their environmental or sustainability reports, through a contrast of a number of large oil companies' non-environmental actions and their constructive sustainability claims. In addition, Ruffing (2007) criticises several award-winning firms, stating that they have not performed as effectively as stated in their social and environmental reports and describes this as both ironic and contradictory. 


\section{Conclusion}

In conclusion, this paper has analysed the developments of ESA and discussed the academic criticism of these developments, specifically the aspect of reporting. Although there have been considerable developments in the area of external social accounting, but, the evidence supports the conclusion that ESA reporting contains some deficiencies and weaknesses. Hence those utilising these reports frequently attain partial and unbalanced assessments of organisational undertakings. As stated by certain authors, this incompleteness could be considered as having sporadic time series, inaccurately estimated data, or unnecessary explanations of calculation methods (Gray, 2005; Fonseca et al., 2013). Moreover, there are a number of critical issues concerning the reporting, including reporting-performance gaps. These gaps include incomplete reporting from the disclosure practice and social auditing practice, along with firms revealing information about their contribution to society in their report, portraying themselves as generous, despite evidence to the contrary.

Finally, many critics believe that firms are using ESA reports to achieve economic and political objectives, rather than environmental and ethical objectives. This belief has been based on the fact that a number of leading firms have not performed as well as they have declared in their social and environmental reports. Therefore this leads to the conclusion that those reports are both worthless and ineffective, as claimed by Adams (2004), Dey (2007) and Milovanović (2009).

\section{References}

Adams, C. (2004). The ethical, social and environmental reporting-performance portrayal gap. Accounting, Auditing \& Accountability Journal, 17(5), 731-757.

http://dx.doi.org/10.1108/09513570410567791

Adams, C., \& Evans, R. (2004). Accountability, Completeness, Credibility and the Audit Expectations Gap. Journal of Corporate Citizenship, 2004(14), 97-115.

http://dx.doi.org/10.9774/gleaf.4700.2004.su.00010

American Institute of Certified Public Accountants. (1977). Objectives of Financial Statements, AICPA, New York, NY.

Anderson, R. H. (1980). Attitudes of chartered accountants to social responsibility disclosure in Australia, Chartered Accountant in Australia, 10(1), 12-16.

Archel, P., Fernández, M., \& Larrinaga, C. (2007). The Organizational and Operational Boundaries of Triple Bottom Line Reporting: A Survey. Environmental Management, 41(1), 106-117. http://dx.doi.org/10.1007/s00267-007-9029-7

Bauer, R., \& Fenn, D. (1972). The corporate social audit. [New York]: Russell Sage Foundation.

Bebbington, J. (2007). Accounting for sustainable development performance. Amsterdam: Cima.

Belal, A. (2002). Stakeholder accountability or stakeholder management: a review of UK 
firms' social and ethical accounting, auditing and reporting (SEAAR) practices. Corporate Social Responsibility and Environmental Management, 9(1), 8-25.

http://dx.doi.org/10.1002/csr.

Blowfield, M., \& Murray, A. (2011). Corporate responsability. New York: Oxford University Press.

Brown, J., \& Fraser, M. (2006). Approaches and perspectives in social and environmental accounting: an overview of the conceptual landscape. Business Strategy and The Environment, 15(2), 103-117. http://dx.doi.org/10.1002/bse.452

Brundland Report. (1987). Our common future. Oxford: Oxford University Press.

Burton, E. (1977). Toward a Theory of Corporate Social Accounting: A Comment. Jstor.org. Retrieved 4 November 2016, from https://www.jstor.org/stable/245598?seq=1\#page_scan_tab_contents

Carrol, A. (1999). Corporate Social Responsibility Evolution of a Definitional Construct. Business Society, 39(3), 268-295. http://dx.doi.org/10.1177/000765039903800303

Casey, P. (2007). Good sustainable development reporting: how and why. Chartered Accountants Journal, 15-16.

Cooper, S., \& Owen, D. (2007). Corporate social reporting and stakeholder accountability: The missing link. Accounting, Organizations And Society, 32(7-8), 649-667.

http://dx.doi.org/10.1016/j.aos.2007.02.001

Day, P., \& Klein, R. (1987). Accountabilities - five public services, London, Tavistock Publications.

Dey, C. (2003). Corporate 'silent' and 'shadow' social accounting. Social And Environmental Accountability Journal, 23(2), 6-9. http://dx.doi.org/10.1080/0969160x.2003.9651696

Dey, C. (2007). Social accounting at Traidcraft plc. Accounting, Auditing \& Accountability Journal, 20(3), 423-445. http://dx.doi.org/10.1108/09513570710748571

Dilley, S. C., \& Weygandt, J. J. (1973). Measuring social responsibility: an empirical test, Journal of Accountancy, 128, 62-70.

Elibirt, H., \& Parket, I. R. (1973). The current status of Corporate Social Responsibility. Business Horizons 16(Aug), 5-14.

Epstein, R., Lattimer, J., \& Schramm, D. (1976). The origin of deuterium. Nature, 263(5574), 198-202. http://dx.doi.org/10.1038/263198a0

Estes, R. W. (1976). Socio-economic accounting and external diseconomies, The Accounting Review, 50(2), 284-90.

Fonseca, A., McAllister, M., \& Fitzpatrick, P. (2013). Sustainability reporting among mining corporations: a constructive critique of the GRI approach. Journal of Cleaner Production, 84, 70-83. http://dx.doi.org/10.1016/j.jclepro.2012.11.050 


\section{Mll Macrothink}

Business and Economic Research ISSN 2162-4860 2017, Vol. 7, No. 1

Foote, J., Gaffney, N., \& Evans, J. (2010). Corporate social responsibility: Implications for performance excellence. Total Quality Management \& Business Excellence, 21(8), 799-812. http://dx.doi.org/10.1080/14783363.2010.487660

Garriga, E., \& Melé, D. (2004). Corporate Social Responsibility Theories: Mapping the Territory. Journal of Business Ethics, 53(1/2), 51-71.

http://dx.doi.org/10.1023/b:busi.0000039399.90587.34

Gibson, K., Gray, R., Laing, Y., \& Dey, C. (2001). The Silent Accounts Project: Draft Silent and Shadow Accounts 1999-2000 (separate publications for Tesco plc and HSBC Holdings plc). Presented to BAA Scottish Group Conference. [Online] Available at:

www.st-andrews.ac.uk/management/csear [Accessed: 18 March 2014].

Gray R. H. (1997). The silent practice of social accounting and corporate social reporting in companies in Zadek S., R.Evans \& P.Pruzan (eds) Building Corporate Accountability: Emerging practices in social and ethical accounting, auditing and reporting pp201-217.

Gray, R. (2002). The social accounting project and Accounting Organizations and Society Privileging engagement, imaginings, new accountings and pragmatism over critique?. Accounting, Organizations and Society, 27(7), 687-708.

http://dx.doi.org/10.1016/s0361-3682(00)00003-9

Gray, R. (2007). Taking a Long View on What We Now Know About Social and Environmental Accountability and Reporting. Issues In Social And Environmental Accounting, 1(2), 169. http://dx.doi.org/10.22164/isea.v1i2.13

Gray R. H., Collison, D. J., French, J., McPhail, K., \& Stevenson, L. (2001). The professional accountancy bodies and the provision of education and training in relation to environmental issues (Edinburgh: ICAS).

Gray, R., Dey, C., Owen, D., Evans, R., \& Zadek, S. (1997). Struggling with the praxis of social accounting. Accounting, Auditing \& Accountability Journal, 10(3), 325-364. http://dx.doi.org/10.1108/09513579710178106

Gray, R., Owen, D., \& Adams, C. (1996). Accounting and accountability (1st ed.). London [etc.]: Prentice Hall.

Gray, R., Owen, D., \& Maunders, K. (1987). Corporate social reporting (1st ed.). Englewood Cliffs: Prentice-Hall International.

Gray, R., \& Milne, M. (2002). Sustainability reporting: Whose kidding whom?, Chartered Accountants Journal of New Zealand, 81(6), 66-70.

Gray. (2006). Social, environmental and sustainability reporting and organizational value creation? Whose value? Whose creation?. Accounting, Auditing \& Accountability Journal, 19(6), 793-819.

Greenwood, M., \& Kamoche, K. (2012). Social accounting as stakeholder knowledge appropriation', Journal of Management and Governance, 
http://dx.doi.org/10.1007/s10997-011- 9208.

Gröjer, J., \& Stark, A. (1977). Social accounting: A Swedish attempt. Accounting, Organizations and Society, 2(4), 349-385. http://dx.doi.org/10.1016/0361-3682(77)90024-1

Gray, R. (1999). The Social Accounting Project and Accounting Organisations and Society: Privileging Engagement, Imaginings, New Accountings and Pragmatism over Critique?. [online]University of St-Andrews. Available at:

https://www.st-andrews.ac.uk/media/csear/discussion-papers/CSEAR_dps-socenv-privengag. pdf [Accessed 4 Nov. 2016].

Hambrick, D., \& Chen, M. (2008). New Academic Fields as Admittance-Seeking Social Movements: The Case of Strategic Management. Academy Of Management Review, 33(1), 32-54. http://dx.doi.org/10.5465/amr.2008.27745027

Hill, D. (1987). Patricia Day and Rudolph Klein, Accountabilities: Five Public Services, Tavistock Publications, London, 1987. 250 pp. paper £9.95. Journal Of Social Policy, 17(02), 262. http://dx.doi.org/10.1017/s0047279400016780

Hopwood, A. (2009). Accounting and the environment. Accounting, Organizations And Society, 34(3-4), 433-439. http://dx.doi.org/10.1016/j.aos.2009.03.002

Horrigan, B. (2010). Corporate social responsibility in the 21st century (1st ed.). Cheltenham, UK: Edward Elgar.

Idowu, S., \& Leal Filho, W. (2009). Professionals' perspectives of corporate social responsibility (1st ed.). Heidelberg: Springer.

Kaspersen, M. (2013). The construction of social and environmental reporting. 1st ed. [Kbh.]: $\mathrm{PhD}$ School of Economics and Management.

Linowes, D. F. (1972). Socio-economic accounting, Journal of Accountancy, 133, 37-42.

Manetti, G. (2011). The quality of stakeholder engagement in sustainability reporting: empirical evidence and critical points. Corporate Social Responsibility and Environmental Management, 18(2), 110-122. http://dx.doi.org/10.1002/csr.255

Mathews, M. (1993). Socially responsible accounting (1st ed.). London: Chapman \& Hall.

Mathews, M. (1997). Twenty - five years of social and environmental accounting research. Accounting, Auditing \& Accountability Journal, 10(4), 481-531.

http://dx.doi.org/10.1108/eum0000000004417

Mathews, M., Perera, M., Chua, F., \& Ng, L. (1991). Accounting theory and development (1st ed.). London: Chapman \& Hall.

Milne, M. J., Tregidga, H., \& Walton, S. (2003). The triple bottom line: benchmarking New Zealand's early reporters. University of Auckland Business Review, 5(2), 36-50.

Milovanović, G., (2009). CORPORATE SOCIAL RESPONSIBILITY IN THE GLOBALIZATION ERA. [Online] Available at: 
< http://facta.junis.ni.ac.rs/eao/eao200902/eao200902-01.pdf $>$ [Accessed 5 Feb. 2014].

Moneva, J., Archel, P., \& Correa, C. (2006). GRI and the camouflaging of corporate unsustainability. Accounting Forum, 30(2), 121-137.

http://dx.doi.org/10.1016/j.accfor.2006.02.001

Mook, L. (2013). Accounting for social value (1st ed.). Toronto, ON: University of Toronto Press.

Murphy, P. E. (1978). An evolution: Corporate Social Responsiveness, University of Michigan Business review, 6(30), 19-25.

O'Dwyer, B., \& Owen, D. (2005). Assurance statement practice in environmental, social and sustainability reporting: a critical evaluation. The British Accounting Review, 37(2), 205-229. http://dx.doi.org/10.1016/j.bar.2005.01.005

O'Sullivan, N., \& O'Dwyer, B. (2009). Stakeholder perspectives on a financial sector legitimation process. Accounting, Auditing \& Accountability Journal, 22(4), 553-587. http://dx.doi.org/10.1108/09513570910955443

Owen D. (2007). Social and Environmental Accounting: Celebrating a silver jubilee of engagement and community" in Gray R.H. and J. Guthrie 2007 (eds) Social Accounting, Mega Accounting and beyond: A Festschrift in Honour of M. R. Mathews (St Andrews: CSEAR Publishing) pp67-76.

Pyatt, G., \& Roe, A. (1977). Social accounting for development planning with special reference to Sri Lanka (1st ed.). Cambridge: Cambridge University Press.

Ramanathan, K. V. (1976). Toward a theory of corporate social accounting, The Accounting Review, 51(3), 516-28.

Ruffing, L. (2007). Silent vs. shadow reports: What can we learn from BP's sustainability report versus the financial times?. Social And Environmental Accountability Journal, 27(1), 9-16. http://dx.doi.org/10.1080/0969160x.2007.9651769

Scerri, A. (2010). Accounting for sustainability. Management Of Environmental Quality: An International Journal, 21(1), 122-135. http://dx.doi.org/10.1108/14777831011010900

Schaltegger, S., \& Wagner, M., (2011). Sustainable entrepreneurship and sustainability innovation: categories and interactions. [online] 20(4), pp.222-237. Available at: <http://onlinelibrary.wiley.com/doi/10.1002/bse.682/abstract> [Accessed 17 Apr. 2014].

Schaltegger, S., Bennett, M., \& Burritt, R. (2006). Sustainability accounting and reporting (1st ed.). Dordrecht: Springer.

Sen, H., (1996). Social Accounting Matrix (SAM) and its implications for macroeconomic planning. [Online] Available at:

<http://www.staff.ncl.ac.uk/david.harvey/AEF873/Development/SAM.pdf> [Accessed 6 Mar. 2014]. 


\section{Macrothink}

Business and Economic Research ISSN 2162-4860 2017, Vol. 7, No. 1

Skouloudis, A., Evangelinos, K., \& Kourmousis, F. (2010). Assessing non-financial reports according to the Global Reporting Initiative guidelines: evidence from Greece. Journal Of Cleaner Production, 18(5), 426-438. http://dx.doi.org/10.1016/j.jclepro.2009.11.015

Spence, C. (2007). Social and environmental reporting and hegemonic discourse. Accounting, Auditing \& Accountability Journal, 20(6), 855-882.

http://dx.doi.org/10.1108/09513570710830272

Stone, R., \& Brown, A. (1962), A Computable Model of Economic Growth. 1edn. Chapman and Hall. London.

Thomson, I., \& Bebbington, J. (2005). Social and Environmental Reporting in the UK: A Pedagogic Evaluation. SSRN Electronic Journal. http://dx.doi.org/10.2139/ssrn.298584

Tregidga, H., \& Milne, M. (2006). From sustainable management to sustainable development: a longitudinal analysis of a leading New Zealand environmental reporter. Business Strategy And The Environment, 15(4), 219-241. http://dx.doi.org/10.1002/bse.534

Ullmann, A. (1985). Data in Search of a Theory: A Critical Examination of the Relationships Among Social Performance, Social Disclosure, and Economic Performance of U.S. Firms. Academy Of Management Review, 10(3), 540-557.

http://dx.doi.org/10.5465/amr.1985.4278989

Wood, J., \& Wood, M. (2004). George Elton Mayo (1st ed.). London: Routledge.

\section{Copyright Disclaimer}

Copyright for this article is retained by the author(s), with first publication rights granted to the journal.

This is an open-access article distributed under the terms and conditions of the Creative Commons Attribution license (http://creativecommons.org/licenses/by/3.0/). 